\section{The Dissocationi Energy and Heat of Formation of the Molecule $\mathrm{NaCu}$}

\section{Vincenzo Piacente}

Istituto di Chimica-Fisica, University of Rome, Rome, Italy

\section{Karl A. Gingerich}

Department of Chemistry, Texas A\& M University, College Station, Texas 77843, USA

(Z. Naturforsch. 28 a, 316-317 [1973]; received 20 January 1973)

The reaction $\mathrm{NaCu}(\mathrm{g})=\mathrm{Na}(\mathrm{g})+\mathrm{Cu}(\mathrm{g})$ has been investigated by means of high-temperature mass-spectrometry, using a double oven technique. From the measured reaction enthalpy the dissociation energy $D_{0}^{0}(\mathrm{NaCu})=41.2 \pm$ $4.0 \mathrm{kcal} \mathrm{mol}^{-1}$ or $172.4 \pm 16.7 \mathrm{~kJ} \mathrm{~mol}^{-1}$ and the standard heat of formation, $\Delta H_{\mathrm{f}, 298}^{0}[\mathrm{NaCu}(\mathrm{g})]=64.3 \pm 4.4 \mathrm{kcal} \mathrm{mol}^{-1}$ or $269.0 \pm 18.4 \mathrm{~kJ} \mathrm{~mol}^{-1}$ have been obtained. The experimental dissociation energy of $\mathrm{NaCu}(\mathrm{g})$ is markedly lower than the value of $54 \mathrm{kcal} \mathrm{mol}^{-1}$ calculated after the Pauling model of a polar single bond.

In a previous investigation of the molecule $\mathrm{NaAg}^{1}$ we have obtained the unexpected result that the dissociation energy $D_{0}^{0}(\mathrm{NaAg})$ is only slighter larger than the average of the dissociation energies of $\mathrm{Na}_{2}$ and $\mathrm{Ag}_{2}$. The PAULING model of a polar bond ${ }^{2}$ that has been found applicable to many intermetallic diatomic molecules 3 would have predicted a considerably higher value. To test further whether this irregularity holds also for the dissociation energies of other diatomic molecules of alkaligroup IB intermetallic compounds we have investigated the molecule $\mathrm{NaCu}$ and report here its dissociation energy and heat of formation.

The instrument and the experimental approach used for the Knudsen cell mass spectrometric investigation were the same as reported previously ${ }^{1}$ except that the Knudsen cell (upper oven) contained copper instead of silver. Only a limited set of data could be obtained for the molecule $\mathrm{NaCu}$, because of the temperature limitations of the experimental apparatus used. The pertinent ions $\mathrm{Na}^{+}, \mathrm{Cu}^{+}$, and $\mathrm{NaCu}^{+}$were identified as originating from the corresponding neutral species in the usual way. The appearance potential of $\mathrm{NaCu}^{+}$was measured as $7.3 \pm 0.7 \mathrm{e} . \mathrm{V}$., with reference to that $\mathrm{Hg}^{+}=10.43$ as a standard ${ }^{4}$. No evidence of a significant fragmentation of $\mathrm{NaCu}$ could be detected.
The ion currents were measured with $45 \mathrm{e} . \mathrm{V}$. electrons. In order to correlate these ion currents with the corresponding partial pressures, a weighed amount of zinc was evaporated immediately following the investigation of the $\mathrm{NaCu}$ molecule, to determine the instrument constant $\left(k_{\mathrm{Zn}}=2.8_{7} \times 10^{-9} \mathrm{~atm} \mathrm{~A}^{-1} \mathrm{~K}^{-1}\right)$. For this purpose, the capillary between the two ovens ${ }^{1}$ was closed. The partial pressures, $P_{\mathrm{i}}$, listed in Table 1 were then obtained using the relation: $P_{\mathrm{i}}=k_{\mathrm{i}} I_{\mathrm{i}}^{+} T$, where $k_{\mathrm{i}}=$ $k_{\mathrm{Zn}_{\mathrm{n}}} \sigma_{\mathrm{Zn}_{\mathrm{n}}} \gamma_{\mathrm{Zn}_{\mathrm{n}}} /\left(\sigma_{\mathrm{i}} \gamma_{\mathrm{i}} n_{\mathrm{i}}\right)$, being the fractional abundance of the measured ion. The relative cross sections for maximum ionization, $\sigma_{\mathrm{i}}$, were taken from MANN ${ }^{5}$ for $\mathrm{Zn}$ (4.65), $\mathrm{Na}$ (4.02), and $\mathrm{Cu}$ (3.80). That for $\mathrm{NaCu}$ was estimated as $0.75(4.02+3.80)=5.87$. The relative multiplier gains, $\gamma_{\mathrm{i}} / \gamma_{\mathrm{Zn}_{\mathrm{n}}}$ were taken from PoTtIE et al. 6 as $1.67(\mathrm{Na})$ and $1.76(\mathrm{Cu})$. The corresponding value for $\mathrm{NaCu}$ was estimated as $(1.67+1.76) / 2=1.72)$.

The enthalpy, $\Delta H_{298}^{0}$, of the reaction

$$
\mathrm{NaCu}(\mathrm{g})=\mathrm{Na}(\mathrm{g})+\mathrm{Cu}(\mathrm{g})
$$

was evaluated by the third-law method using the relation $\Delta H_{298}^{0} / T=-R \ln K_{\mathrm{p}}-\Delta\left[\left(G_{\mathrm{T}}^{0}-H_{298}^{0}\right) / T\right]$. The necessary values for the free energy functions, $\left(G_{\mathrm{T}}^{0}-H_{298}^{0}\right) / T$, were taken from literature for $\mathrm{Na}$ and $\mathrm{Cu}^{7}$. Those for $\mathrm{NaCu}(\mathrm{g})$ were calculated in an analogous manner as those for $\mathrm{NaAg}(\mathrm{g})^{1}$ from estimated molecular parameters $\left(r_{\mathrm{e}}=2.45 \AA, \omega_{\mathrm{e}}=290 \mathrm{~cm}^{-1}\right.$, and a ' $\Sigma$ ground state) yielding $-\left(G_{\mathrm{T}}^{0}-H_{0}^{0}\right) / T$ values of $62.53,63.09$ and $63.62 \mathrm{cal} \mathrm{mol}^{-1} \mathrm{~K}^{-1}$ for $T=1500,1600$ and $1700 \mathrm{~K}$, respectively. With $\left(H_{298}^{0}-H_{0}^{0}\right)=2.345 \mathrm{kcal}$ $\mathrm{mol}^{-1}$ the respective values for $-\left(G_{\mathrm{T}}^{0}-H_{298}^{0}\right) / T$ of $64.10,64.56$ and $65.00 \mathrm{cal} \mathrm{mol}^{-1} \mathrm{~K}^{-1}$ are obtained. Table 1 includes the logarithms of the equilibrium constants, the free energy function changes, and the enthalpy changes for Reaction (1). The error term in the average value given for the reaction enthalpy, $\Delta H_{298}^{0}=$ $41.8 \pm 0.3 \mathrm{kcal}$ represents the standard deviation. The corresponding $\Delta H_{0}^{0}$ value of $41.2 \pm 0.3 \mathrm{kcal}$ is obtained using the enthalpy increments, $H_{298}^{0}-H_{0}^{0}$, from literature for $\mathrm{Na}$ and $\mathrm{Cu}^{7}$ and the calculated value for $\mathrm{NaCu}$. From the experimental reaction enthalpy the dissociation energy, $D_{298}^{0}(\mathrm{NaCu})=41.8 \pm 4.0 \mathrm{kcal} \mathrm{mol}^{-1}$ or $174.9 \pm 16.7 \mathrm{~kJ} \mathrm{~mol}^{-1}$, or $D_{0}^{0}(\mathrm{NaCu})=41.2 \pm$ $4.0 \mathrm{kcal} \mathrm{mol}^{-1}$ or $172.4 \pm 16.7 \mathrm{~kJ} \mathrm{~mol}^{-1}$ is obtained. Here the error term takes also the uncertainties in the temperature measurement, the calibration constant, the free energy functions and in the relative ionization

Tab. 1. Third-Law Enthalpies for the Reaction $\mathrm{NaCu}(\mathrm{g})=\mathrm{Na}(\mathrm{g})+\mathrm{Cu}(\mathrm{g})^{\mathrm{a}}$.

\begin{tabular}{|c|c|c|c|c|c|c|}
\hline$T\left({ }^{\circ} \mathrm{K}\right)$ & $\begin{array}{l}P_{\mathrm{Na}^{+}} \\
\text {atm }\end{array}$ & $\begin{array}{l}P_{\mathrm{Cu}^{+}} \\
\text {atm }\end{array}$ & $\begin{array}{l}P_{\mathrm{NaCu}^{+}} \\
\text {atm }\end{array}$ & $-\log K_{\mathrm{p}}$ & $\begin{array}{l}-\Delta\left[\left(G_{\mathrm{T}}^{0}-H_{298}\right) / T\right] \\
\text { ca1 } \mathrm{K}^{-1}\end{array}$ & $\begin{array}{l}\Delta H_{298}^{0} \\
\mathrm{kcal}\end{array}$ \\
\hline 1640 & $6.53 \times 10^{-5}$ & $6.64 \times 10^{-5}$ & $4.70 \times 10^{-8}$ & $1.03_{5}$ & $20.5_{3}$ & 41.4 \\
\hline 1675 & $7.00 \times 10^{-5}$ & $1.07 \times 10^{-4}$ & $7.04 \times 10^{-8}$ & $0.97_{5}$ & $20.5_{5}$ & 41.9 \\
\hline 1680 & $1.14 \times 10^{-4}$ & $1.07 \times 10^{-4}$ & $1.16 \times 10^{-7}$ & $0.97_{5}$ & $20.5_{5}$ & 42.0 \\
\hline
\end{tabular}

a $\Delta H_{298}^{0}=41.8 \pm 0.3 \mathrm{kcal} ; \Delta H_{0}^{0}=41.2 \pm 0.3 \mathrm{kcal}$. 
cross-sections and multiplier gains into account as well as the fact that only a limited amount of data could be obtained. Combining $D_{298}^{0}(\mathrm{NaCu})$ with the standard heats of vaporization $7, \Delta H_{\mathrm{v}, 298}$ of sodium $(25.6 \pm$ $\left.0.1 \mathrm{kcal} \mathrm{mol}^{-1}\right)$ and copper $\left(80.5 \pm 0.3 \mathrm{kcal} \mathrm{mol}^{-1}\right)$ the standard heat of formation, $\Delta H_{\mathrm{f}, 298}^{0}[\mathrm{NaCu}(\mathrm{g})]=$ $64.3 \pm 4.4 \mathrm{kcal} \mathrm{mol}^{-1}$ or $269.0 \pm 18.4 \mathrm{~kJ} \mathrm{~mol}^{-1}$ results.

The value, $D_{0}^{0}(\mathrm{NaCu})=41.2 \mathrm{kcal} \mathrm{mol}^{-1}$ is by $10 \mathrm{kcal} \mathrm{mol}-1$ larger than the average of $D_{0}^{0}\left(\mathrm{Na}_{2}\right)=$ $17.3 \mathrm{kcal} \mathrm{mol}^{-1}$ and $D_{0}^{0}\left(\mathrm{Cu}_{2}\right)=45.0 \mathrm{kcal} \mathrm{mol}^{-1}\left(\mathrm{see}^{3}\right)$. The bond energy, $D(\mathrm{NaCu})$ calculated after the Pauling model of polar bond 2 is $54 \mathrm{kcal} \mathrm{mol}^{-1}$, that is by $13 \mathrm{kcal} \mathrm{mol}^{-1}$ larger than the experimental value. As in the case of $\mathrm{NaAg}$ the model does not predict correctly the actual dissocation energy and overemphasizes apparently the ionic contribution to the bond energy. But unlike as for $\mathrm{NaAg}$ a noticable ionic contribution to the bonding is observed for $\mathrm{NaCu}$. More experimental determinations of dissociation energies of similar gaseous intermetallic compounds are indicated before a deeper insight into the particular bonding behavior can be gained.
We want to express our gratitude to Professor G. DeMaria for helpful discussions and to the C.N.R. Centro di Chimica delle Alte Temperature and the National Science Foundation for the support of this work.

1 V. Piacente and K. A. Gingerich, High Temp. Science 4, 312 [1972].

2 L. Pauling, The Nature of the Chemical Bond, 3rd ed., Cornell University Press, Ithaca, New York 1960.

3 K.A. Gingerich, J. Cryst. Growth 9, 31 [1971]

4 R.W. KISER, Introduction to Mass Spectrometry and Its Applications, Prentice-Hall, Engelwood Cliffs, New Jersey 1965.

5 J.B. ManN, in Recent Development in Mass Spectrometry, Proc. of the Intern. Conf. on Mass Spectrom., Kyoto, K. Ogata and T. Hayakawa, Eds., University of Tokyo Press, 1970, pp. 814-819.

6 R.F. Pottie, D. L. Cocke, and K.A. Gingerich, Int. J. Mass Spectrom. Ion Phys. 11, 41 [1973].

7 R. Hultgren, R. Orr, and K. K. Kelly, Supplement to Selected Values of Thermodynamic Properties of Metals and Alloys, University of California, Berkeley, CA., 1968 $[\mathrm{Cu}], 1971[\mathrm{Na}]$. 